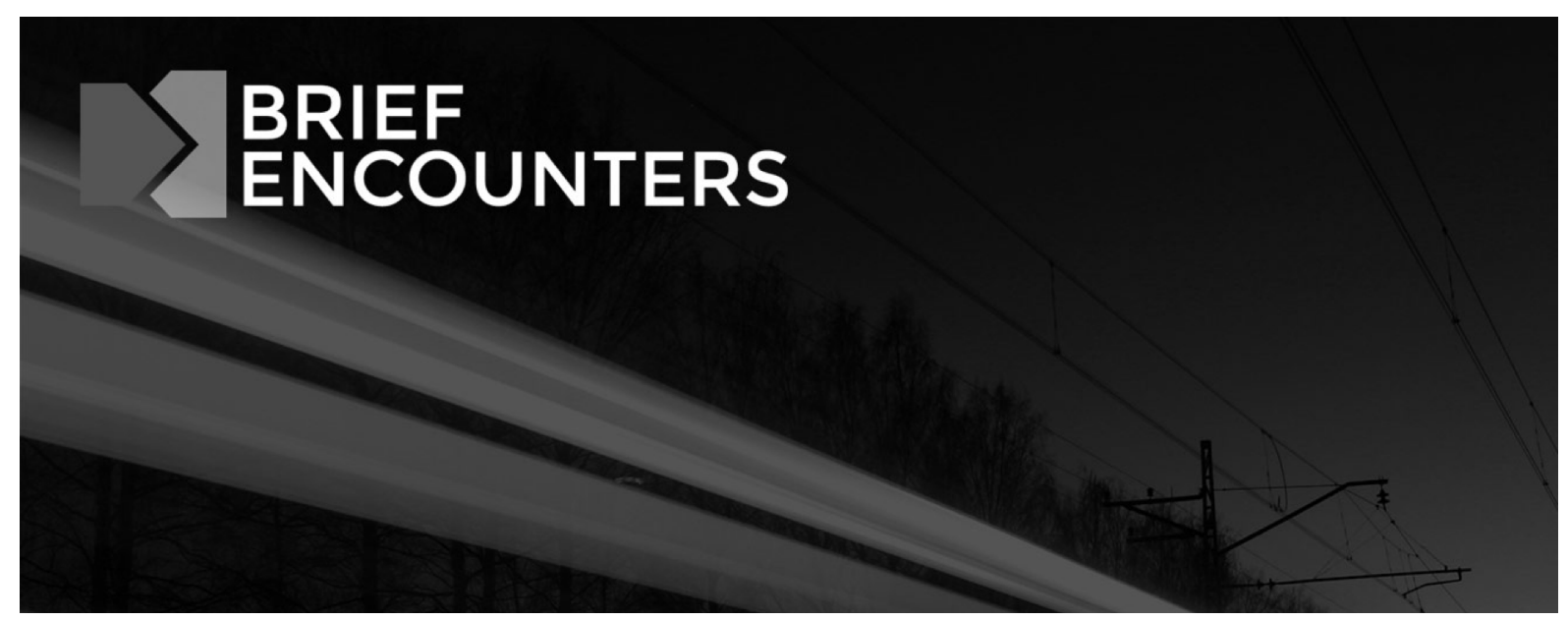

ISSN 2514-0612

Journal homepage: http://briefencounters-journal.co.uk/BE

From Modernism to Metro Maps: Mondrian, Beck, and Salomon

Author(s): Peter B. Lloyd

Email: pbl@kent.ac.uk

Source: Brief Encounters Vol.1, No. 1 (Feb 2017)

URL: http://briefencounters-journal.co.uk/BE/article/view/38/

DOI: http://dx.doi.org/10.24134/be.v1i1.38

(C) Peter B. Lloyd, 2017

License (open-access): This is an open-access article distributed under the terms of the Creative Commons Attribution License 4.0, which permits unrestricted use, distribution, and reproduction in any medium, provided the original work is properly cited. No warranty, express or implied, is given. Nor is any representation made that the contents will be complete or accurate or up to date. The publisher shall not be liable for any actions, claims, proceedings, demand or costs or damages whatsoever or howsoever caused arising directly or indirectly in connection with or arising out of the use of this material.

Brief Encounters is an open access journal that supports the dissemination of knowledge to a global readership. All articles are free to read and accessible to all with no registration required. For more information please visit our journal homepage: http://briefencounters-journal.co.uk/BE. 


\section{From Modernism to Metro Maps: Mondrian, Beck, and Salomon}

Peter B. Lloyd

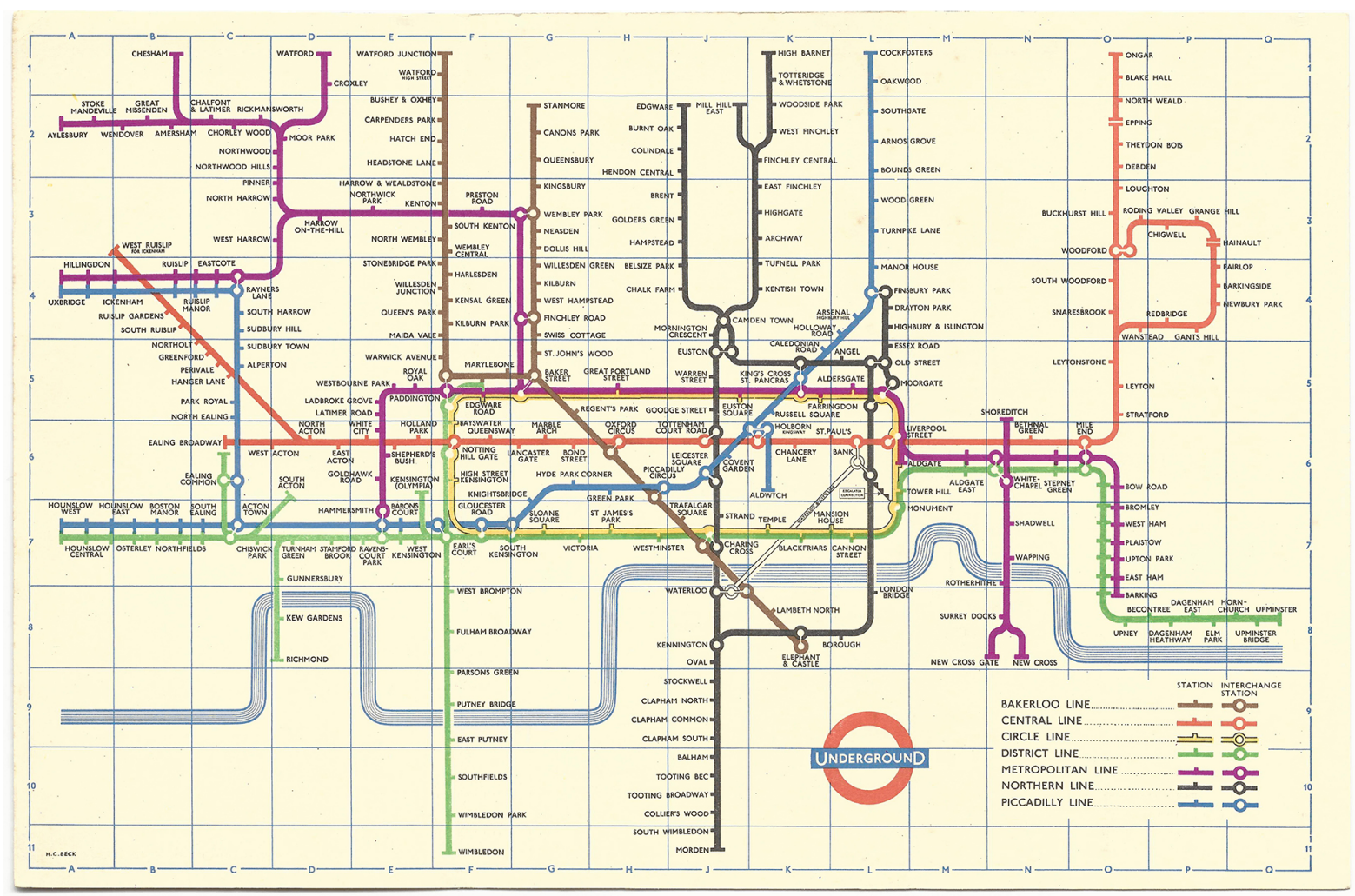

Fig. 1. Henry C. Beck, Underground / Diagram of Lines and Station Index, 1958, trifold card, $22.6 \times 14.8 \mathrm{~cm}$, printed lithographic edition of 500,000, London Transport, author's private collection. @TfL from the London Transport Museum collection <http://www.Itmuseum.co.uk/>.

Could metro maps, such as the London Tube Map, derive some of their inspiration from the high art of the Dutch painter Piet Mondrian (1872-1944)? Many have hinted at it. Although it seems incongruous to propose a connection between creative artistry and the quotidian task of wayfinding in a public transport network, there is a point of contact between Mondrian and metro maps which I will explore here. I will argue that this contact is latent in Henry Beck's design of the London Underground map (see Fig. 1); but that it becomes explicit in the similar work of George Salomon, who designed a diagrammatic map of the New York City subway (see Fig. 2). 


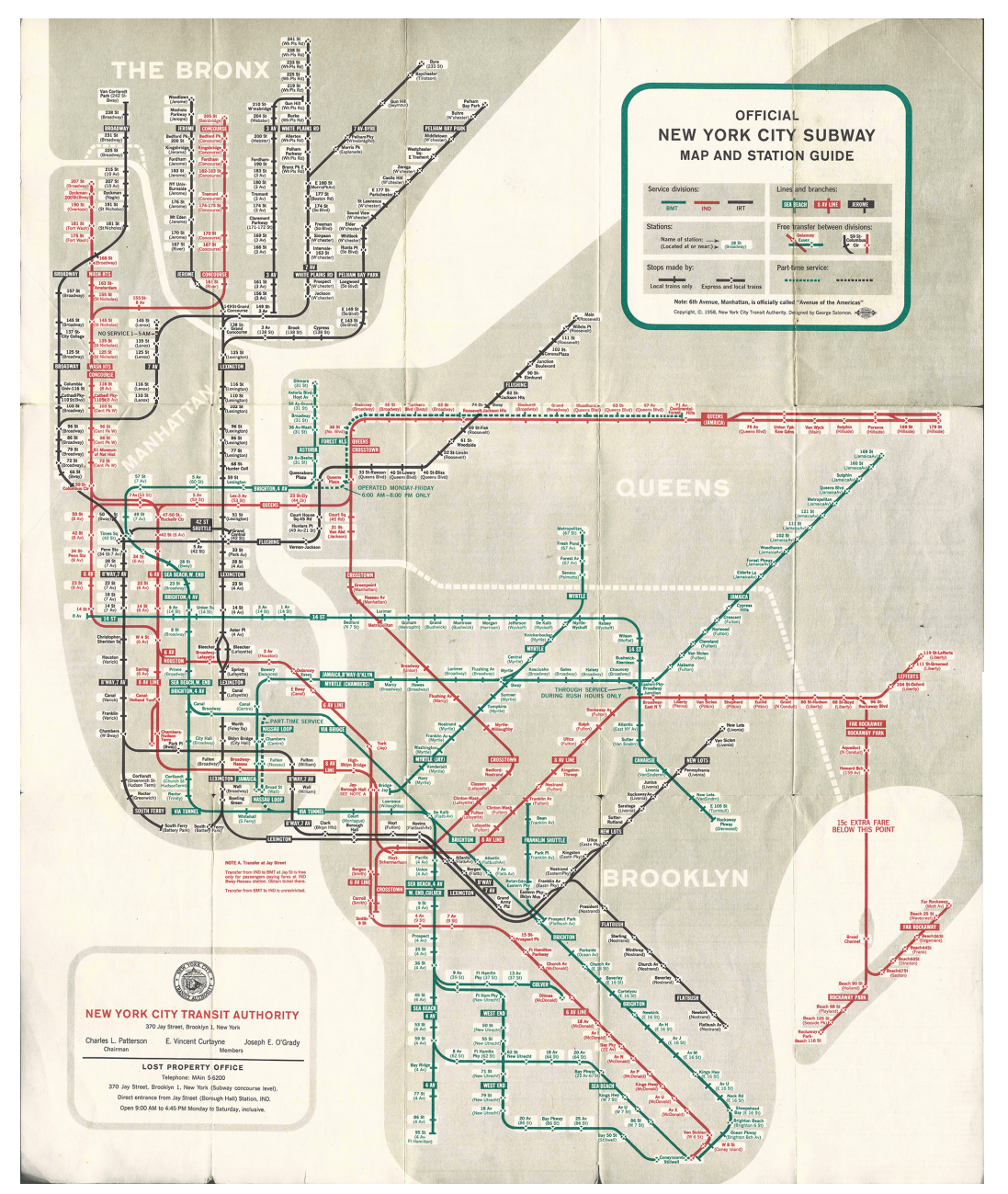

Fig. 2. George Salomon, Official New York Subway Map and Guide, 1958, folded sheet, $41.3 \times 19.5 \mathrm{~cm}$, printed lithographic edition, New York City Transit Authority, author's private collection. (C) 1958, New York Transit Museum.

\section{Schematising Metro Maps}

Maps of light rail systems or 'metros' are often schematised to make them clearer, turning them into diagrammatic, rather than geographic, maps. Schematising a map involves three main changes, which Maxwell Roberts and Doug Rose recently summarised: '1) Omission of surface details other than the most important landmarks'; '2) Simplification of line trajectories'; '3) Global and/or local scale distortion'. ${ }^{1}$ The first two changes lighten what psychologists call the 'cognitive load' of reading the map. Features such as streets and cemeteries give the brain more details to digest, even if it then ignores them as irrelevant to navigating the metro. So stripping out topographic features and smoothing out kinks in the metro lines reduces the information the brain has to cope with, allowing a passenger to

\footnotetext{
${ }^{1}$ Maxwell J. Roberts and Doug Rose, 'Map-induced Journey-planning Biases for a Simple Network: A Docklands Light Railway study', Transportation Research Part A, 94 (2016), 446-460 <https://doi.org/10.1016/j.tra.2016.09.023> [accessed 9 January 2017] (p. 447).
} 


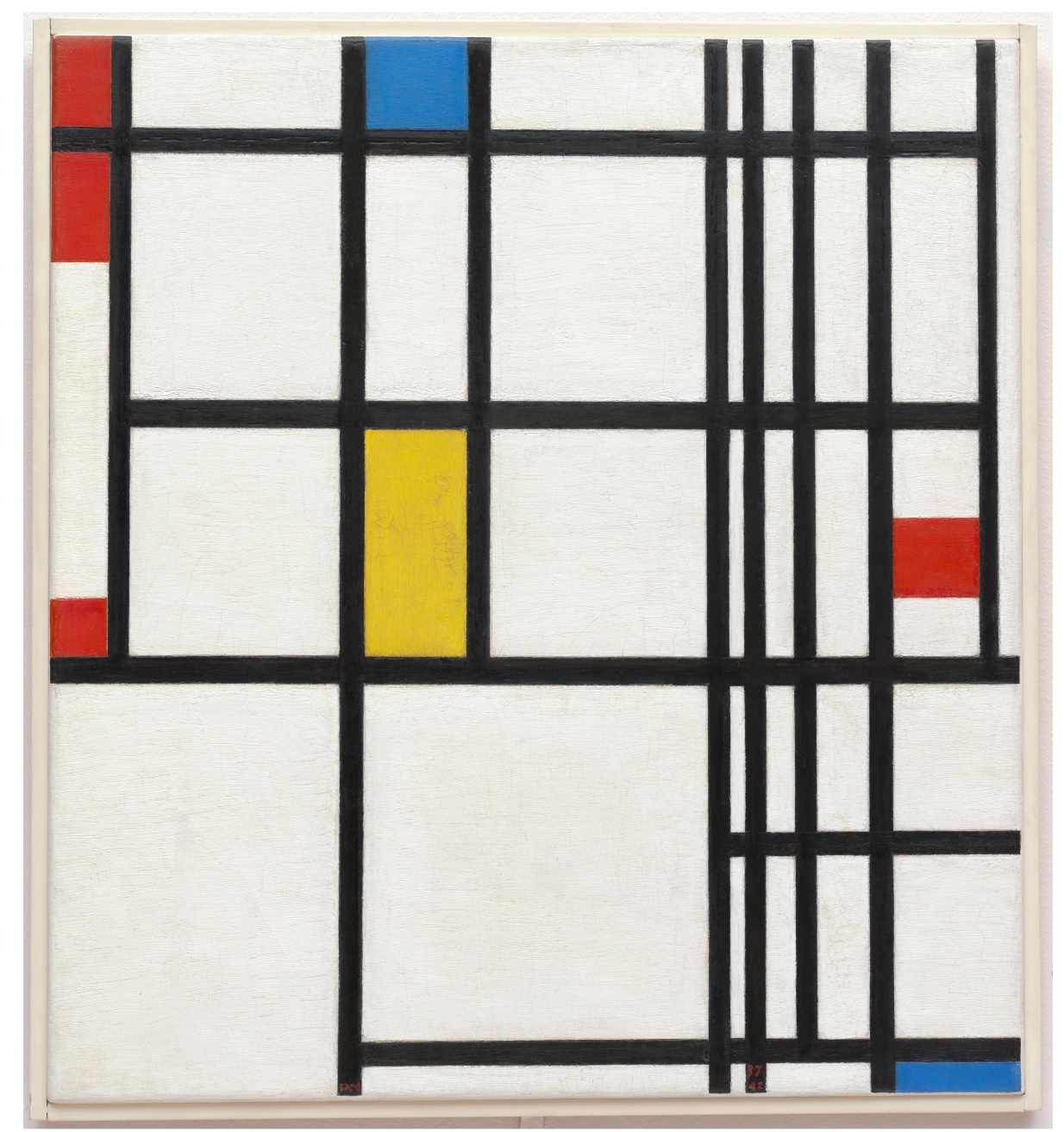

Fig. 3. Piet Mondrian, Composition in Red, Blue, and Yellow, 1937-1942, oil on canvas, 23 3/4 x 21 7/8" $(60.3 \times 55.4 \mathrm{~cm})$. The Sidney and Harriet Janis Collection, The Museum of Modern Art (MoMA), New York.

Digital Image (C) The Museum of Modern Art, New York. Photo: John Wronn.

follow the map more quickly, with less stress and fewer mistakes. The third schematising change is for legibility. Usually, the old town of a big city has denser metro stations than the suburbs. This is certainly true of inner London and downtown New York. To avoid overcrowding that part of the map and making it hard to read, its scale is greatly increased, while the scale in the suburbs is reduced.

All these schematic features can be seen in the London map. Only the River Thames remains to orient us to the city; distances between stations are expanded in the centre, and shrunk in the periphery; and routes are aligned to horizontal, vertical, and $45^{\circ}$ diagonal directions, with stations strung out at uniform intervals. 
Being diagrammatic does not by itself make a map easy to read, let alone elegant or iconic. ${ }^{2}$ Beck and Salomon schematised their maps with a sensibility that gave them an aesthetic punch. To identify that sensibility, let us consider whether any commonalities can be seen in the work of Mondrian, Beck, and Salomon, and then ask what insights art and science might yield.

\section{Piet Mondrian}

In 1917, Piet Mondrian and Theo van Doesburg (1883-1931) founded the journal De Stijl, which catalysed an art movement of the same name, and became a key vector of modernist art. Mondrian's work from the 1920s onwards was distinctive for his construction of paintings from horizontal and vertical black lines and blocks of solid colour (see Fig. 3). He was the most austere of the modernist painters, and in 1925 split from Doesburg, partly because Mondrian found diagonals anathema while Doesburg found them indispensable. (Coincidentally or not, the distaste for diagonals was also seen in Henry Beck's map of the London Underground, where especially in the 1950s he strove to remove diagonals from the map - at great cost to geographic realism, with neighbouring stations being pulled into distant points on the map in order to produce a grid formation.) Mondrian was unusual in being very forthcoming about his thoughts on his art: in the first eleven issues of De Stijl, he published his long essay 'Neoplasticism in Painting' in which he articulated his drive toward abstraction. In 1918 he wrote:

The truly modern artist consciously perceives the abstractness of the emotion of beauty: he consciously recognises aesthetic emotion as cosmic, universal. This conscious recognition results in an abstract creation, directs him toward the purely universal. That is why the new art cannot be manifested as (naturalistic) concrete representation, which [...] always points more or less to the particular, or in any case conceals the universal within it. The new plastic cannot be cloaked by what is characteristic of the particular,

\footnotetext{
${ }^{2}$ A comparison of good and bad diagrammatic metro maps is offered by Maxwell J. Roberts and Ida C. N. Vaeng, 'Expectations and Prejudices Usurp Judgements of Schematic Map Effectiveness', Design Research Society 50th Anniversary Conference, Brighton, 27-30 June 2016 <http://www.tubemapcentral.com/articles/Roberts_Vaeng_DRS2016_2016.pdf> [accessed 13 November 2016].
} 
natural form and colour, but must be expressed by the abstraction of form and colour - by means of the straight line and determinate primary colour. ${ }^{3}$

The parallel between Mondrian's paintings and metro maps lies in the expression of deep, abstract structures beneath the surface. In an analogous way, the modernist map must eschew the incidental details of particular trips through the metro and details of track layout to reveal instead the common structure of the pattern of routes, a 'deeper reality' to be captured in a diagrammatic map using rectilinear forms of pure colours.

There is, however, more to Mondrian than this. From the early 1930s, he extended this form of abstraction with what he called 'dynamic equilibrium'. As usual, he was keen to articulate this change, and wrote that the equilibrium in the new art is not a static state without action, as is generally thought but, on the contrary, a continuous and mutually annihilating opposition of equivalent but unequal elements'. ${ }^{4}$ Could this dynamic equilibrium also be the key to the striking elegance of iconic metro maps?

\section{Henry Beck}

A relationship between Mondrian's paintings and Beck's map has been hinted by several authors. For example, Ken Garland, in his seminal work on Beck's map, wrote: 'it might have been expected that the advent of such an abstract, schematised image would generate a response similar to one's first sight of a Mondrian painting: respectful, awed, intrigued, maybe mystified, but surely never affectionate? Yet it was so.. ${ }^{5}$ More recently, information designer Luca Rosati observed that 'Beck was not a graphic designer, but an engineerdesigner, and his map was inspired by the representations of electrical circuits, and by cubism

\footnotetext{
3 Piet Mondrian, 'Neoplasticism in Painting', in De Stijl, trans. by R. R. Symonds and ed. by Hans L. C. Jaffé (London: Thames and Hudson, 1970), pp. 36-93 (p. 36).

4 Piet Mondrian, 'The New Art-The New Life: The Culture of Pure Relationships', in The New Art-The New Life: The Collected Works of Piet Mondrian ed. and trans. by Harry Holtzman and Martin S. James (Boston: Da Capo Press, 1986), p. 252.

${ }^{5}$ Ken Garland, Mr Beck's Underground Map (Harrow Weald: Capital Transport Publishing, 1994), p. 19.
} 
and abstract art (Mondrian)', while art critic Tom Lubbock remarked on how the map 'looks a bit like a Mondrian abstract'.6 Similarly, literary critic Ira Nadel declared:

The streamlined map [...] is a visual expression of the modernist aesthetic capturing, through its lucidity, a sense of speed, direction, and purpose freed from reality. Another important feature is colour, combined with its closed system evoking a Mondrian grid implicit in the form. The simplification of a complex urban network prompted one historian [Eric Hobsbawm] to claim the tube map is the most original work of avant-garde art produced in Britain between the wars. ${ }^{7}$

These writers point out a surface similarity between the Underground map and Mondrian's paintings, but hint at something more. As we shall now see, Mondrian cannot have influenced Beck, but I shall suggest that they independently used the same idea.

Mondrian was not precious about artistic painting as a vehicle for manifesting the universal ideal of elegance in a particular artefact: 'Abstract-real life is not found exclusively in art, science or religion: it can be realised in them, but can also be lived in any of life's activities.' ${ }^{8}$ He would see nothing incongruous in our finding Neo-Plasticism in a Tube map. Yet the suggestion of a substantive connection between Mondrian and Beck is often derided by the art establishment. I shall argue below that this connection is real but comes from a shared inspiration rather than any historical link. So let us first look at Mondrian's obscurity in England when Beck drew his map, and see that Mondrian and Beck must have had their ideas independently.

James Elkins, an art critic at the School of the Art Institute of Chicago, dismissed Garland's book as merely 'entertaining' and wrote, that, 'as Garland knows, there is no

\footnotetext{
${ }^{6}$ Luca Rosati, 'La mappa della metropolitana di Londra: una lezione di information design', Lucarosati (19 November 2008) <http://lucarosati.it/blog/mappa-metropolitana-di-londra> [accessed 18 June 2015] (para 3 of 4). The original text reads: 'Beck non era un grafico, ma un ingegnere-disegnatore, e per la sua mappa si ispirò alle rappresentazioni dei circuiti elettrici, così come all'arte cubista e astratta (Mondrian)'. See Tom Lubbock, 'Great Works: The London Underground Map (1931)', The Independent, 14 August 2009 < http://www.independent.co.uk/arts-entertainment/art/great-works/great-works-the-londonunderground-map-1931-1771565.html> [accessed 18 June 2015].

${ }^{7}$ Ira B. Nadel, Modernism's Second Act, A Cultural Narrative (New York: Palgrave, 2013), p. 71.

8 Piet Mondrian, 'Neoplasticism in Painting', p. 80.
} 
evidence that Beck was interested in Mondrian or modernism'. ${ }^{9}$ As a close friend of Beck, Garland later confirmed that 'Beck knew nothing of Mondrian, De Stijl or the Bauhaus until the 1950s; and even when he did become acquainted, saw no connection with his own work'. ${ }^{10}$ Indeed, Beck himself did not ascribe his inspiration for the map to anything more than a desire to 'tidy up' the existing map, which had been drawn by his predecessor Fred Stingemore in the 1920s:

Looking at the old map of the Underground railways, it occurred to me that it might be possible to tidy it up by straightening the lines, experimenting with diagonals and evening the distance between stations. The more I thought about it the more convinced I became that the idea was worth trying, so, selecting the Central London Railways as my horizontal base line I made a rough sketch. I tried to imagine that I was using a convex lens or mirror, so as to represent the central area on a larger scale. This, I thought, would give a needed clarity to the interchange information. ${ }^{11}$

Mondrian's work was unknown in England when Beck was first sketching his map in 1931, as it was only from 1934 that Ben Nicholson started promoting Mondrian in London, and the first international exhibition of abstract art to be held in Britain was Nicolete Gray's Abstract \& Concrete touring exhibition of 1934-35, including three works by Mondrian. It was not well received by the British media or art circles. The Daily Mail described it as 'at best, a jolly leg pull', and the auction house Christie's saw no monetary value in it. It was only after the exhibition toured Oxford and Liverpool that any London gallery deigned to show it. Mondrian's three paintings were offered at $£ 50$ each but no buyer could be found, and the only two that sold were bought by Gray and her friend, Helen Sutherland. ${ }^{12}$ Whilst it is true that Beck had an interest in matters on the other side of the English Channel, as evidenced by

\footnotetext{
9 James Elkins, Visual Studies: A Skeptical Introduction (London: Routledge, 2003), p. 180.

${ }^{10}$ Ken Garland, email to author, 11 June 2015.

${ }^{11}$ Garland, Beck's Underground Map, p. 17.

12 Frances Spalding, 'Abstract Art: From the Radical to the Everyday', The Guardian, 10 January 2015 <http:// www.theguardian.com/artanddesign/2015/jan/10/geometric-abstraction-exhibition-whitechapel-gallery-london-malevichblack-square> [accessed 28 May 2015].
} 
his map of the Paris Metro, there is no reason to think that he was aware of Mondrian (who lived in Paris from 1919 to 1934) or the Bauhaus school (which in 1931 had not yet been dispersed from its German nucleus).

As cited above, the eminent Marxist historian Eric Hobsbawm (1917-2012) apparently linked Beck to modern art, but this needs to be qualified. In 1998, Hobsbawm delivered a lecture at the National Gallery, saying that the avant-garde practitioners had abrogated their role as artists by giving up the traditional vocation of communicating with an audience, without replacing it with anything else. ${ }^{13}$ Only in the applied modernist arts of the Bauhaus and similar endeavours did he see any merit. These programmes sought to harness innovative artistic techniques for practical purposes, including the improvement of wayfinding in public transport systems:

The most original work of avant-garde art in Britain during the wars was not produced as a work of art at all, but as an efficient technical solution for a problem of how to present information: it is the map of the London underground system. Incidentally, the bankruptcy of the avant-garde is vividly demonstrated by the pointless adaptation of this by Simon Patterson in this year's 'Sensation' show. ${ }^{14}$

Hobsbawm did not mean that Beck was a product of the avant-garde, but that what Beck did was the kind of thing that the avant-garde should have been doing.

All this shows that Beck did not belong to the historical lineage of Mondrian. Nevertheless, both were independently engaged in similar intellectual processes: deconstructing familiar but superficial visual detail; discovering a deeper, abstract structure; and articulating it in a lucid visual form that possessed a strong aesthetic force.

\footnotetext{
${ }^{13}$ Eric Hobsbawm, Behind the Times: The Decline and Fall of the Twentieth-Century Avant-Gardes (London: Thames and Hudson, 1999), p. 38.

14 Ibid., p. 39. The reference to Simon Patterson alludes to his graphic work The Great Bear (1992), which was a four-colour offset lithograph reproduction of the current London Underground map, in which the station names were replaced with essentially random names of celebrities. It was exhibited in the Sensation show at the Royal Academy of Art from 18 September to 28 December 1997. Although Hobsbawm says it 'vividly demonstrates the bankruptcy of the avant-garde', in fact it demonstrates the bankruptcy of post-modernism and its petulant refusal to mean anything.
} 


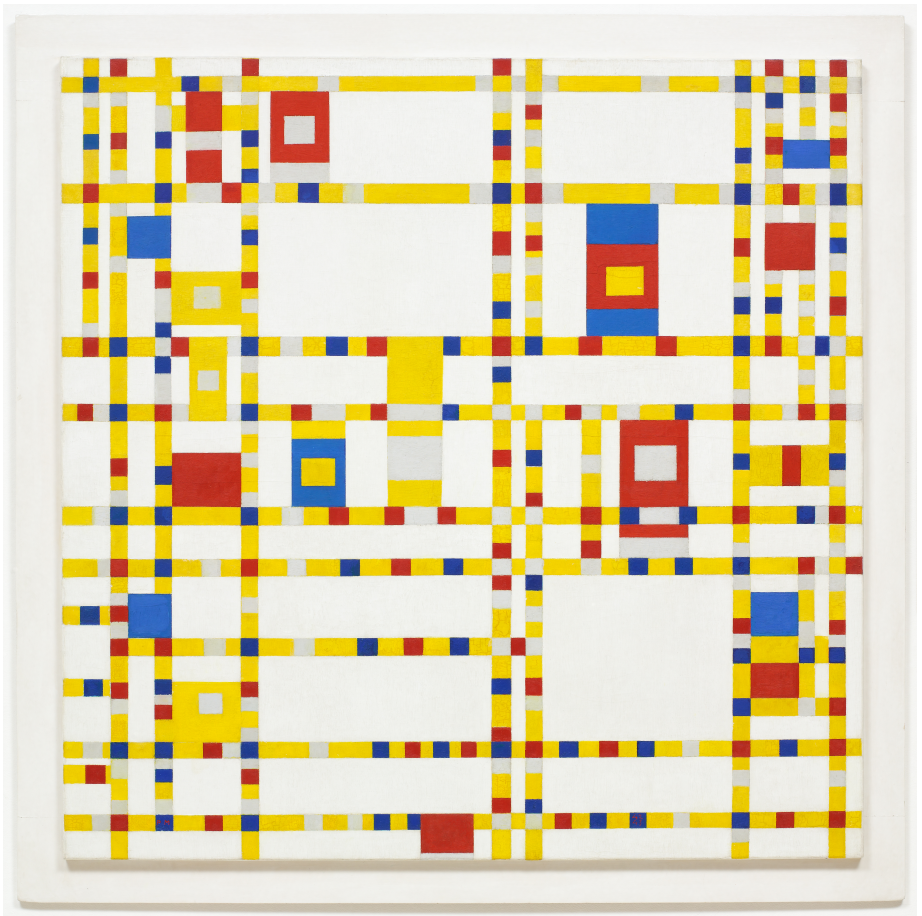

Fig. 4. Piet Mondrian, Broadway Boogie-Woogie, 1942-43, oil on canvas, $50 \times 50 "$ (127 × $127 \mathrm{~cm})$, The Museum of Modern Art (MoMA), New York. Digital Image (C) The Museum of Modern Art, New York. Photo: Jonathan Muzikar.

\section{George Salomon}

We have seen that Mondrian did not inspire Beck, but did he inspire Salomon? Mondrian left his adopted home town of Paris in 1938 to escape European fascism, moving first to London that year and to New York in 1940. George Salomon coincidentally moved to New York in the same year as Mondrian, who by this time was sufficiently well respected to have several of his paintings hanging in the city's Museum of Modern Art (MoMA). In 1937, MoMA had acquired Composition in White, Black, and Red (painted 1936); and, in 1941, the year after Mondrian's arrival, his Composition No. II, with Red and Blue (1929) was acquired for MoMA by Philip Johnson. The artist gave MoMA his Broadway Boogie-Woogie (1942-43) shortly before his death in 1944 (see Fig. 4). Salomon's son, Frank, says his father admired Mondrian and frequented art galleries, so we can assume that he would have seen these paintings by the time he embarked on his proposals to the New York City Transit Authority in the mid-1950s. Unlike cosy Hampstead, Manhattan embraced Abstract Expression with vigour, and public exhibitions of the style were held in New York from the mid-1940s. In 1951, MoMA's exhibition Abstract Painting and Sculpture in America brought public focus and legitimacy to this innovative movement for 
abstract painting. Although Mondrian is not always counted as a member of the Abstract Expressionist group, as he died just as the movement in New York was gaining momentum, nevertheless his status as a major influence on the movement is well established.

As I mentioned above, Mondrian was rare among major artists in being prolific in writing about his practice. His theories first appeared in English in 1937 and the first substantive collection of his essays in English was published in $1945 . .^{15}$ Hence, unlike Beck in the 1920s, Salomon in the 1950s would have had easy access to at least the main elements of Mondrian's thinking.

So, Salomon was exposed to the work of Mondrian, but did it influence his map? The aesthetic modality that Mondrian articulated in his essays on Neo-Plasticism can indeed be seen in the abstraction of an aesthetically coherent diagram from the messy geography of the city's transportation system. In both cases the aim is to regard surface reality as non-significant clutter and strip it away, and to use a pure visual language to elegantly articulate a deeper reality.

In later editions of Salomon's subway map, the Transit Authority added to his map a series of markers for forty-six Places to Visit, ranging from the Aquarium to the Yankee Stadium. Why should these sites be privileged? These Places to Visit are the traces of particular visitors. Salomon, in designing a map in the same spirit as Mondrian, discarded these concrete particulars and engaged instead with the connectivity that is universal for all riders of the subway. For example, a rider who is travelling from Times Square to $161^{\text {st }}$ Street must ride the $7^{\text {th }}$ Avenue line to Grand Concourse and transfer to the Jerome line. This is irrespective of whether the rider is going to the Yankee Stadium, or going to some other destination in the neighbourhood. The same thinking led Salomon to drop from the map the particular twists and turns that beset the actual tracks, and present instead straight lines that cleanly embody the connections of the network.

\footnotetext{
15 Piet Mondrian, 'Plastic Art and Pure Plastic Art', in Circle: An International Survey of Constructivism, ed. by Ben Nicholson, Naum Gabo and Leslie Martin (London: Faber \& Faber, 1937), pp. 41-56; Piet Mondrian, Piet Mondrian, Plastic Art and Pure Plastic Art, 1937, and Other Essays, 1941-1943 (New York: Wittenborn and Company, 1945).
} 
Salomon did not 'base' his design on Mondrian, but I suggest that Mondrian's work sensitised Salomon to the innovative concept of seeking out a deeper structure and intuitive beauty through asymmetrical balance and dynamism, and of revealing that structure in a disciplined visual language. Being influenced by Mondrian does not necessarily mean following him, it can also mean reacting against him, as Frank Salomon relates about his father's choice of colour scheme for the subway: '[He liked] modernity with a somewhat softened edge. I remember him thinking so long and hard about colours for that map. Broadway Boogie-Woogie was great but those kind of colours give an artefact a somewhat nervous look and harsh on the eye. He wanted to avoid that.'16

\section{Dynamic Equilibrium}

It does not matter that a metro map also guides riders through the subway: the diagram bears an aesthetic of its own that is orthogonal to its utilitarian dimension. It is like architecture: a building serves a practical purpose of providing a space to live or work in, but it also has an aesthetic authority. ${ }^{17}$

Elkins argues that Beck's inspiration was the mathematical discipline of topology rather than art, but in fact Elkins conflates those two orthogonal but related dimensions in which a subway diagram must work, namely the pragmatic and the aesthetic. ${ }^{18}$ On the one hand, the diagram is constrained to be a correct representation of the topology of the network of routes; on the other hand, it must also speak directly to the sensibilities of the viewer. Let us extend Mondrian's terminology to metro maps. As a first analysis, the topology of transit routes constitutes a 'deeper reality' that can be appreciated only through an abstract visual language, and is made clearer by omitting superficial topographical details.

\footnotetext{
${ }^{16}$ Frank Salomon, interviewed by the author, 23 July 2015.

17 See, for example, Abdulaziz Al-Saati's detailed argument for Neo-Plasticism's influence on architecture: Abdulaziz Al-Saati, 'Mondrian: Neo-Plasticism and its influences in Architecture', Journal of the Faculty of Architecture of the Middle East Technical University (M.E.T.U.), 10.1-2 (1990), 63-74 <http://jfa.arch.metu.edu.tr/archive/0258-5316/1990/cilt10/ sayi_1_2/63-74.pdf> [accessed 28 May 2015].

18 Elkins, pp. $180-182$.
} 
Further, however, I suggest that Beck and Salomon also moulded the subway to a deeper and more elusive aesthetic reality, essentially Mondrian's dynamic equilibrium.

Converting a train map into a diagram does not, by itself, yield an iconic image. It remains information engineering rather than art. In all the masterpieces of subway design those of Beck, Salomon, Massimo Vignelli, Lance Wyman, for instance - there is a deeper engagement that strives to manifest a universal sense of elegance, which appears intuitive rather than rational. ${ }^{19}$ We are led, by both Mondrian's paintings and by the great subway maps, to an inward contemplation of a timeless elegance, apprehended by intuition rather than by any calculus.

Mondrian's work introduced the belief that a numinous quality of beauty could be brought out by focusing on non-representational blocks of colour. Thus Mondrian wrote: 'Through the plastic expression of composition, [the] rhythm, proportion and equilibrium (which replaces regularity or symmetry) can be perceived clearly. The exactness with which Neoplasticism expresses these laws of harmony allows it to achieve the greatest possible inwardness.'20 Mondrian was drawn to mystical religions, and Neo-Plasticism owes a debt to the other-worldly philosophy of Neo-Platonism. Mondrian held that our fragmentary and transient perception of the manifest world is an imperfect derivative of some more fundamental structure, and that what we call 'beauty' exists in that deeper, Platonic substratum of the world rather than the ephemeral superstructure. The painter's task is to see through the superficial 'natural reality' and discern that deeper 'abstract reality', and then to express that abstract reality through the disciplined but harmonious use of a limited visual language comprising blocks of primary colours plus black, white, and gray, and solid black lines.

The hypothesis of a Platonic realm is not testable empirically, and our first resort should be to suppose that whatever Mondrian expressed in his paintings, including the

\footnotetext{
${ }^{19}$ For the contributions of Massimo Vignelli to the metro maps of New York and Washington, see Peter B. Lloyd, Vignelli: Transit Maps (Rochester: RIT Press, 2012).

20 Piet Mondrian, 'Neoplasticism in Painting', p. 59.
} 
'dynamic equilibrium', actually exists in information patterns that are cognisable by the human brain. Can computer science help us discover those patterns?

\section{Computer Science}

In the 1990s, Dr Chris McManus, a psychologist at UCL, began a series of experiments to test whether people can tell a genuine Mondrian image from a computer-generated random variation of the artist's work. ${ }^{21} \mathrm{He}$ found that a small but statistically significant majority of subjects could correctly identify the genuine Mondrians.

What this seems to tell us is that people are cognitively latching on to some organisational feature of Mondrian's design that is aesthetically pleasing to the mind, and yet does not lend itself to conscious analysis: the participants could not say what precisely was distinctive about the real Mondrians.

An analogous problem bedevils the automated design of metro maps. ${ }^{22}$ At the University of Essex, Dr Maxwell Roberts has been carrying out innovative research into establishing a framework of rules for the successful design of metro maps, based on empirical studies of usability. ${ }^{23}$ Given this framework, students who have never designed a metro map before are able to produce new maps that are often better than the official maps issued by the metro companies themselves. ${ }^{24}$ But, so far, attempts to automate the design of metro layouts have not produced maps with a comparable aesthetic quality. And, for large systems such as London, computers have not yet produced an even remotely acceptable map. It is

\footnotetext{
21 Ian Christopher McManus, B. Cheema and J. Stoker., 'The Aesthetics of Composition: A Study of Mondrian', Empirical Studies of the Arts, 11 (1993), 83-94 <https://doi.org/10.2190/HXR4-VU9A-P5D9-BPQQ> [accessed 28 May 2015]. See also Ian Christopher McManus, "The anti-developmental, the anti-narrative, the anti-historical": Mondrian as a Paradigmatic Artist for Empirical Aesthetics', Behavioral and Brain Sciences, 36.2 (2013), 152-153 <https://doi.org/10.1017/ S0140525X12001720> [accessed 28 May 2015].

22 See Jonathan M. Stott and Peter Rodgers, 'Automatic Metro Map Design Techniques', Proceedings of the 22nd International Cartographic Conference (Barcelona: International Cartographic Association, 2005), p. 10. See also Jonathan M. Stott, 'Automatic Layout of Metro Maps Using Multicriteria Optimisation' (unpublished doctoral thesis, University of Kent, 2008).

${ }^{23}$ Maxwell J. Roberts, 'Understanding Schematic Mapping through Usability and Design Experiments', The Cartographic Journal (forthcoming, 2017).

24 Presentation of student projects at the University of Essex, observed by the author (2015).
} 
possible that a full implementation of Roberts' framework might do the job, but I suggest that something akin to Mondrian's dynamic equilibrium needs to be added. For the framework has to be followed in a sensitive way to get a good result, a sensitivity that has yet to be captured in software. Perhaps that elusive element is a sensitivity to what Mondrian called dynamic equilibrium, and perhaps that sensitivity is what leads people to compare Beck's maps to Mondrian's paintings. To investigate this, however, requires that dynamic equilibrium be given a rigorous enough definition that it can be operationalised in computer software. How to understand this aesthetic element in metro maps is one of the central questions in current research on their design. 


\section{Bibliography}

Agani, Asaf A., 'A Tale of Two Maps: Analysis of the London Underground "Diagram"', Ergonomics in Design: The Quarterly of Human Factors Applications, 21.3 (2013), 7-16 <https://doi.org/10.1177/1064804613489125> [accessed 28 May 2015]

Al-Saati, Abdulaziz, 'Mondrian: Neo-Plasticism and its influences in Architecture', Journal of the Faculty of Architecture of the Middle East Technical University (M.E.T.U.), 10.1-2, (1990), 63-74 <http://jfa.arch.metu.edu.tr/archive/0258-5316/1990/cilt10/ sayi_1_2/63-74.pdf> [accessed 28 May 2015]

Ashton-Smith, Alan, 'Algebra of the Visual: The London Underground Map and the Art It Has Inspired', NANO (New American Notes Online), 1 (2011) <http://nanocrit.com/issues/ issue-1-navigation-all/algebra-visual-london-underground-map-and-art-it-hasinspired> [accessed 17 June 2015]

Elkins, James, Visual Studies: A Skeptical Introduction (London: Routledge, 2003)

Garland, Ken, Mr Beck's Underground Map (Harrow Weald: Capital Transport Publishing, 1994)

Garland, Ken, email to author, 11 June 2015

Hobsbawm, Eric, Behind the Times: The Decline and Fall of the Twentieth-Century AvantGardes (London: Thames and Hudson, 1999)

Holtzman, Harry, and Martin S. James, eds., The New Art-The New Life: The Collected Works of Piet Mondrian (Boston: Da Capo Press, 1986)

Jaffé, Hans L. C. ed., De Stijl, trans. by R. R. Symonds and Mary Whitall (London: Thames \& Hudson, 1970) 
Lloyd, Peter B., Vignelli: Transit Maps (Rochester: RIT Press, 2012)

Lubbock, Tom, 'Great Works: The London Underground Map (1931)', The Independent, 14 August 2009 <http://www.independent.co.uk/arts-entertainment/art/great-works/ great-works-the-london-underground-map-1931-1771565.html> [accessed 18 June 2015]

McManus, Ian Christopher, "'The anti-developmental, the anti-narrative, the anti-historical": Mondrian as a Paradigmatic Artist for Empirical Aesthetics', Behavioral and Brain Sciences, 36.2 (2013), 152-153 <https://doi.org/10.1017/S0140525X12001720> [accessed 28 May 2015]

McManus, Ian Christopher, B. Cheema, and J. Stoker, 'The Aesthetics of Composition: A Study of Mondrian', Empirical Studies of the Arts, 11 (1993), 83-94 <https://doi.org/ 10.2190/HXR4-VU9A-P5D9-BPQQ> [accessed 28 May 2015]

Mondrian, Piet, Le Néo-Plasticisme: Principe général de l'équivalence plastique (Paris: Editions de l'Effort moderne, 1920)

Nadel, Ira B., Modernism's Second Act, A Cultural Narrative (New York: Palgrave, 2013) <https://doi.org/10.1057/9781137323378> [accessed 28 May 2015]

Nicholson, Ben, Naum Gabo, and Leslie Martin, Circle: An International Survey of Constructivism (London: Faber \& Faber, 1937)

Roberts, Maxwell J., 'Understanding Schematic Mapping through Usability and Design Experiments', The Cartographic Journal (forthcoming, 2017)

Roberts, Maxwell J., and Doug Rose, 'Map-induced Journey-planning Biases for a Simple Network: A Docklands Light Railway Study', Transportation Research Part A, 94 (2016), 446-460 <https://doi.org/10.1016/j.tra.2016.09.023> [accessed 9 January 2017] 
Roberts, Maxwell J., and Ida C.N. Vaeng, 'Expectations and Prejudices Usurp Judgements of Schematic Map Effectiveness', Design Research Society 50th Anniversary Conference, Brighton, 27-30 June 2016 <http://www.tubemapcentral.com/articles/ Roberts_Vaeng_DRS2016_2016.pdf> [accessed 13 November 2016]

Rosati, Luca, 'La mappa della metropolitana di Londra: una lezione di information design', Lucarosati (19 November 2008) <http://lucarosati.it/blog/mappa-metropolitana-dilondra> [accessed 18 June 2015]

Mondrian, Piet, Plastic Art and Pure Plastic Art, 1937, and Other Essays, 1941-1943 (New York: Wittenborn and Company, 1945)

Salomon, Frank, interviewed by author, 23 July 2015

Spalding, Frances, 'Abstract Art: From the Radical to the Everyday', The Guardian, 10 January 2015 <http://www.theguardian.com/artanddesign/2015/jan/10/geometricabstraction-exhibition-whitechapel-gallery-london-malevich-black-square> [accessed 28 May 2015]

Stott, Jonathan M., and Peter Rodgers, 'Automatic Metro Map Design Techniques', in Proceedings of the 22nd International Cartographic Conference (Barcelona: International Cartographic Association, 2005)

Stott, Jonathan M., 'Automatic Layout of Metro Maps Using Multicriteria Optimisation' (unpublished doctoral thesis, University of Kent, 2008) 